\title{
THE STRUCTURE OF EXECUTIVE POWER. THE STRUCTURE'S EVOLUTION OF THE EXECUTIVE POWER IN ROMANIA O. Şaramet
}

\author{
Oana Şaramet \\ Faculty of Law, Law Department \\ "Transilvania" University of Braşov, Braşov, Romania \\ *Correspondence: Oana Şaramet, Transilvania University of Brasov, \\ 25 Eroilor St., Brasov, Romania \\ E-mail: oana saramet_2005@yahoo.com
}

Abstract: The monist or dualist character of the executive, a character determined by the structure of the executive, must not be mistaken for the monist or dualist character of the parliamentary regime, in which case the government is still at "the center of attention" but from a different perspective.

\section{Keywords: executive power, structure, monocratic, dualist, evolution}

\section{Introduction}

The appearance of the parliamentary regime determined the need for a second organ of executive power ${ }^{1}$, namely Govern, who is politically liable in front of the parliament, unlike the head of the state - be it monarch or president - who is irresponsible from this point of view. Thus, in regard to structure, we can distinguish between the monocratic or monist ${ }^{2}$ executive and the dualist or bicephalous ${ }^{3}$ or bifurcate executive. $^{4}$

The monist parliamentary regime was specific to the classical from and considered "the double necessity of the cabinet to have the trust of the parliament and the head of the state" because, in essence, the classic parliamentary regime meant the powers were separated. This was translated by the constant collaboration between the head of the state and the parliament through the government. Unlike the monocratic system, the dualist one, specific to modern parliamentary regime meant the government had the Parliament's trust ${ }^{5}$.

\section{Monocratic executive}

Doctrine $^{6}$ appreciates that the executive is monocratic or monist when the executive function is entrusted to a single state entity. It is also stated ${ }^{7}$ that this form of the executive can be seen when the decision is focused in the hands of a single organism. Thus, we can talk about a monocratic or monist executive when a single public authority of the state exercises executive power.

\footnotetext{
1 T. Drăganu, Drept constituţional şi instituţii politice. Tratat elementar, vol. II, "Lumina Lex” Publishing House, Bucharest, 2000, p. 308.

${ }^{2}$ See I. Vida, Puterea executivă şi administraţia publică, Regia Autonomă "Monitorul Oficial” Publishing House, Bucharest, 1994, p. 31 and following.

${ }^{3}$ See A. Hauriou, Droit constitutionnel et institutions politiques, "Montchrestien” Publishing House, Paris, 1972, p. 653.

${ }^{4}$ T. Drăganu, Drept constituţional şi instituţii politice. Tratat elementar, vol. II, "Lumina Lex" Publishing House, Bucharest, 2000, p. 308.

${ }^{5}$ See A. Hauriou, Droit constitutionnel et institutions politiques, "Montchrestien" Publishing House, Paris, 1972, p. 209.

${ }^{6}$ I. Vida, Puterea executivă şi administraţia publică, Regia Autonomă "Monitorul Oficial” Publishing House, Bucharest, 1994, p. 31.

${ }^{7}$ D.C. Dănişor, Drept constituţional şi instituţii politice. Exerciţiul puterii în stat, vol. II, "Europa” Publishing House, Craiova, 1996, p. 99.
} 
Starting from this statement, we can see that such an executive structure was specific to absolute monarchies where there was no separation of powers. Thus, the one who had power, namely the monarch, regardless of the title - king, lord, emperor, prince, emir and so on exercised power in al its aspects, passing laws, administering and acting as a judge. The advisers, ministers $^{8}$ or workers who assisted the monarch were not all a part of a collegial body similar to the present government as they were not considered to be a distinctive authority in the state with own duties and prerogatives. On the other hand, their role was that of advising the monarch, sometimes even discussing his orders and dispositions. The word "monarchy" represents the from of organization, of governing of a state in which "executive power is entrusted...to a single person""; the origin of this word is Greek, as "monos" means "alone" and "arhi" - "reign".

As is the case of absolute monarchies, in case of dictatorship regimes, the mixing of powers has determined that the power holder, thus the holder of executive power, to be one organism, be it unipersonal or collegial.

In regard to these mentions and starting from the assumption that all current monarchies are thought to have a more symbolic character, we feel that it is necessary to state if parliamentary monarchies, especially those from the European continent, still have a monocratic executive or if it was replaced by the dualist executive or if it became more particular.

In the United Kingdom, the symbolic character of the monarchy is maybe the most visible, as, at least in theory, the holder of executive power is the monarch; in practice "her majesty's ministers" are the ones who exercise power, led by the prime-minister who will answer to the Parliament ${ }^{10}$; however, there are constitutional regulations of other states, such as Denmark, Holland, Belgium, countries which can impose contrary opinions.

Thus, for example, section 12 of Denmark's Constitution ${ }^{11}$ clearly states that the King, with limitations stated by the Constitution, has supreme authority in regard to all the kingdom's affairs and will exercise supreme authority through ministers who are, according to section 14, named and revoked by the monarch, including the prime-minister. All their tasks will be established by the monarch. Sections 17 and 18 of the same legal act regulate two organisms, the State Council formed of the ministers - holders of ministerial bodies, the Heir to the Throne ruled on by the King and the Minister's Council, who is formed of the ministers and presided by the prime-minster. The Distinction between these two organisms is not only in regard to their component and the person who presides it as section 17 alignment (2) corroborated with section 18 establishes a rule of priority for the State Council, namely all projects of law and all important government measures will be discussed by the council only if the King was prevented from calling de State Council, thus subjecting these to the debate of the Minister's Council. Furthermore, the same section 18 states that, after the Minister's Council reaches a decision, the prime-minster is obliged to inform the king who will decide whether to embrace the recommendations of the Minister's Council or to bring that specific problem to the attention of the State's Council. Unlike the Danish constitutional regulations, the Dutch ones stated that the King is part of the Government, along with the ministers [article 42 alignment (1)]. However, according to the provisions of article 45 alignments (1) - (3) the ministers along with the primeminister from the Council of Ministers, who is presided by the prime-minister, the person who decides on governmental policy and who will ensure and promote its coherence. However, in the Dutch constitutional system, according to article 43, the prime-minister and the ministers are named and revoked by the king, through regal decree.

\footnotetext{
${ }^{8}$ The term "minster" is used to designate the advisers of the monarch. This word no longer has the same significance nowadays, that of dutiful, servant.

${ }^{9}$ P. Negulescu, Curs de drept constituţional român, published by Alex. Th. Doicescu, Bucharest, 1928, p. 413.

${ }^{10}$ Also see Elena Simina Tănăsescu, N. Pavel (coordinators), Actele constituţionale ale Regatului Unit al Marii Britanii şi Irlandei de Nord, in the Collection "Constitutions of the States of the World, All Beck Publishing House, Bucharest, 2003, pp. 5 and following.

${ }^{11}$ Similar provisions to those of the Danish Constitution are found in the Norwegian Constitution. See the provisions of articles 12-13.
} 


\section{O. Şaramet}

In regard to these two constitutional examples, we will point out that the Danish executive, by the fact that it provides the monarch a considerable power of decision which is not to be found in the provisions of Holland's Constitution, is significantly closer to the real monocratic executive. On the contrary, the Dutch executive can only formally be monocratic, as it seems to be more a dualist executive, as is the case of most contemporary monarchies, in our opinion.

The evolution from absolute monarchy to parliamentary monarchy or contemporary republics, as well as the influence of the principle of separation and equilibrium of powers in the state will determine, most times, the abandonment of the monocratic executive in favor of the dualist one.

Given all these, the monocratic executive model was assumed by states with a presidential regime, where the holder of the executive power is the president of the republic. The most eloquent example is that of the president of the United States of America ${ }^{12}$ who, by the provisions of article 2 paragraph 1 point 1 of the Constitution, is granted all executive power.

The American presidential regime overstepped the boundaries of the state where the 1787 Constitution was born, but each of the states ${ }^{13}$ that used it as a model, brought upon an "institutional innovation"14, namely the Government, who along with the President - head of the state, form executive power. This "alteration" of the presidential regime did not affect the nature of the regime, an aspect pointed out by doctrine ${ }^{15}$ and by the constitutional regulations, especially those regarding the functions and attributions of the President.

\section{The dualist executive}

Unlike the monocratic executive, the dualist one entails the exercising of executive power by two distinctive bodies, one of those being unipersonal - the head of the state - and usually called de president and the other a collegial body with specific attributions, by name of government - the most common and used name, ministerial cabinet or minister's council.

The appearance of the dualist executive was determined, as we have mentioned previously, by the appearance and spreading of the of the parliamentary regime, in which the constant collaboration of powers, of the head of state with the parliament, called for the creation of this organ who, initially, was supposed to benefit from the trust of the head of state, as well as the parliament.

The evolution in time of the parliamentary regime will force the collegial body to only benefit from the confidence of the parliament. On the other hand, this evolution will determine several particularities for each state, sometimes even within the same state, particularities regarding the parliamentary regime and the executive in general, with priority given to the collegial body.

\footnotetext{
${ }^{12}$ We must point out that although the United States' Constitution did not regulated a collegial body to exercise executive power along with the President, some presidents, like Alexander Hamilton or Thomas Jefferson tried to reunite the leaders of the federal executive departments in order to easily coordinate them. Their existence is stated by article 2 paragraph 2 point 1 of the Constitution. Their attempt failed as it was later pointed out by the politicalconstitutional American reality. For details - see J.Q. Wilson, American Government. Institutions and Policies, Harvard University and University of California, Los Angeles, 1986, p. 330.

${ }^{13}$ Such examples are Argentina or the Russian Federation. In both cases, although executive power is entrusted to the president, the constitutional regulation of a collegial body - the Government - an exponent of the executive, makes us think that is an exaggeration to describe these systems as moncratic, at least on a formal level. The executive was dualist and the President had a favorable position. See I. Vida, Puterea executivă şi administraţia publică, Regia Autonomă "Monitorul Oficial” Publishing House, Bucharest, 1994, p. 34; J. P. Jacqué, Droit constitutionnel et institutions politiques, "Dalloz" Publishing House, Paris, 2003; V. Duculescu, Constanţa Călinoiu, G. Duculescu, Constituţia României - comentată şi adnotată, "Lumina Lex" Publishing House, Bucharest, 1997, pp. 572, 580-586.

${ }^{14}$ I. Vida, Puterea executivă şi administraţia publică, Regia Autonomă "Monitorul Oficial” Publishing House, Bucharest, 1994, p. 34.

${ }^{15}$ Ibidem.
} 
In regard to the reports within the dualist executive system, we can notice that in these modern parliamentary regimes, the role of the head of the state - president or monarch - is increasingly similar to the symbolic role of the monarch, as the task of exercising the executive power is given to the government.

A particular situation is seen in case of semi presidential or parliamentary republics, as they are characterized by part of the doctrine. Especially the relations between the president and the prime minister will be significantly influenced by the evolution of the political scene, but also by the personality of those who temporarily hold these dignities. Thus, although constitutional lawmakers who chose to organize the powers of a state by following the rules of a such a regime as the French one, have reconfigured the role of the president, by letting go of his symbolic character; there was no transformation of the president in the head of the executive power and the elimination of the prime-minister or his transformation in a "puppet" of the first one. So, even though we can appreciate that the source of inspiration of the institution of president of the state is the Orleans ${ }^{16}$ parliamentary regime, we can't say that the institution of the president is a copy of it. We must also point out that one of the aspects which bring it close to the Orleans parliamentary regime is that of giving significant attributions to the president, even own attributions (like the one to dissolve the legislative or one of the rooms of the legislative, the right to exercise some attributions and elaborate decrees without the signature of the primeminister) without benefiting from theoretical rights which are, in fact, exercised by the responsible ministers. We can even state that in a semi presidential regime, the president doesn't have the effective power to govern, as he is not a substitute for the government or the prime minister. His role is strictly centered on the quality of referee ${ }^{17}$, a statement which is all the more correct in case of semi presidential regimes in an extenuating from or in case of semi parliamentary regimes, as it is out current constitutional regime.

The relations between the president and the government, namely the prime-minister, within a semi presidential regime are of collaboration similar with those of a parliamentary regime. However, these relations can suffer in a semi presidential regime when the president is not also the chief of parliamentary majority, as he is forced "to coexist" with it, but most of all, with its leader - the prime-minister, in which case none of his constitutional duties allow him "to paralyze the activity of the government or the parliament" ${ }^{\text {, }}$, by allowing him to exercise his veto rights when there is a joint decision ${ }^{19}$ to be made by him and the prime-minster. In these times, we can talk about the functioning of a "cabinet government" similar to the British one, by mentioning that the prerogatives of the president are not merely symbolic, as representation of the honorific presiding of some state organisms.

\footnotetext{
${ }^{16}$ The Orleans parliamentary regime represented an intermediary phase between limited monarchy and modern parliamentary regimes and appeared in France when the Chart of 1830 was applied as interpreted by King LouisPhilippe off the dynasty d' Orleans (hence the name of this regime). This involved the existence of a dualist executive in which the head of the state had important powers, but was separate from the collegial Government, who was liable to the Parliament. The constitutional reform of 1962 even if inspired from this from of parliamentary regime „deformed” it not towards a presidential regime, but towards parliamentary one. See M. Duverger, Les constitutions de la France, „P.U.F.” Publishing House, Paris, 1987, pp. 63-65, 106-107.

${ }^{17}$ M. Duverger, Les constitutions de la France, „P.U.F.” Publishing House, Paris, 1987, pp. 106-107.

${ }^{18}$ Idem, p. 117.

${ }^{19}$ Such duties can be found in the French Constitution or even in the Portuguese one. We mention duties like: signing ordinances and decrees of the Minister's Council (French Constitution - art. 13 alignment 1), the passing of laws, law-decrees, regulatory decrees, signing the resolutions of the Republic's Assembly of acknowledging international agreements, as well as other Government's Decrees (Portuguese Constitution - art. 137 letter b) or the possibility of the President to organize a referendum by request of the Government, any law regarding the domains stated in article 11 alignment (1) of the French Constitution, namely relevant national issues which must be subject of referendum under the conditions stated by article 137 letter c) corroborated with article 118 of the Portuguese Constitution. The possibility of exercising the veto right by the President, in both examples, is translated by his refusal to act according to the constitution.
} 


\section{O. Şaramet}

We can't ignore the fact that even within the government, there is a tendency of growth ${ }^{20}$ of the prime minister's role in the detriment of the other ministers, given that the majority of constitutions $^{21}$, in order "to avoid the risk of an authoritarian prime minister to replace a minister by imposing a certain political trace and not the political line of the program which is accepted by the parliament" 22 , states that he coordinates the activity of the ministers, by respecting the specific attributions of each and every one of them. However, the prime minister's attempt to turn his primus inter pares positions from the government to that of primus inter partes is more and more visible.

\section{The evolution of the executive's structure in Romania}

The regulations of the Developing Statute of the 7/19 august 1958 Convention, especially those of article I corroborated with those of articles II, III and V, according to which The Lord was entrusted will all public powers, while the legislative power was exercised by the Lord together with the two Legislative Assemblies, describe a monocratic or monist executive.

Subsequently, by passing the 1866 Constitution, the parliamentary regime ${ }^{23}$ was introduced, as well as monarchy as a form of government. In regard of the structure, the Constitution itself provides a clue, by stating in article 35 the fact that executive power is entrusted to the King who will exercise it by its own regulations. Thus, we are in the presence of a monocratic or monist executive system, the unipersonal body which was entrusted with exercising this power being originally called "the Lord", while, later on, following the 1881 proclamation of the Kingdom of Romania, it became known as "The King".

The 1923 Constitution will maintain, among other previous constitutional regulations, the provisions of article 36 of the 1866 Constitution, which are to be found in article 39 . As opposed to this, this fundamental law will set out the Government by pointing out, in article 92, that the Government exercises legislative power in name of the King in the way established by the Constitution. This attention given by the lawmaker to the Government or Minister's Council did not transform the Romanian executive of that time from a monocratic one to a dualist one ${ }^{24}$. The same point of view is found in inter war doctrine ${ }^{25}$ and it is based on the fact that the rule was to entrust executive power to one organism which was unipersonal ${ }^{26}$, but also on the fact that the holder of sovereignty - the nation - by organizing the way sovereignty was about to be exercised,

\footnotetext{
${ }^{20}$ Such an example is the Lithuanian Constitution (passed by the Lithuanian legislative on October 25th, 1992, acknowledged by the President of the Supreme Council of the Republic of Lithuania 15 days since it was passed by referendum) which, in article 96, states that the ministers lead ,the spheres” of administration which were entrusted to them, but they are under the direct supervision of the prime-minister.

${ }^{21}$ Thus, article 65 of the Fundamental Law of the Federal Republic of Germany states that the political guidelines are set by the Federal Chancellor and each federal minister leads his own department independently and responsibly. A similar provision can be found in the Slovenian Constitution (this constitution was passed on December 23rd, 1991, being subsequently revised three times, in 1997, 2000 and 2003), thus, article 114 alignment (1) mentions that he president of the Government is responsible for ensuring the unity of political and administrative leadership of the Government by coordinating the activity of the ministers.

${ }^{22}$ M. Constantinescu, A. Iorgovan, I. Muraru, Simina Elena Tănăsescu, Constituţia României revizuită - comentarii și explicaţii, „All Beck” Publishing House, Bucharest, 2004, p. 181.

${ }_{23}^{23}$ C. Ionescu, Tratat de drept constituţional contemporan, ,All Beck” Publishing House, Bucharest, 2003, p. 491

${ }^{24}$ According to a contrary opinion, executive power was exercised by the Government in the name of the King. The Government held the real decision-making power through the prime-minister. C. Ionescu, Contemporary constitutional law treaty, op. cit., page 509. An argument in favor of this statement could be that although the King had the right to legislative initiative, King Ferdinand never exercised this right, as the government was the one that elaborated projects of law which ere then presented to the king through a Journal of the Minister's Council. Acknowledging a formal monocratic executive doesn't seem plausible for those times, especially since, at that time in history, Europe's monarchs play a significant role in history.

${ }^{25}$ See P. Negulescu, Curs de drept constituţional român, published by Alex. Th. Doicescu, Bucharest, 1928, pp. 413 and following.

${ }^{26}$ Exceptions from this rule: the French Directorate of the 1875 Constitution, The Swiss Federal Council regulated by the 1874 Swiss Constitution, the regal lieutenancy, regency and the Minister's Council, regulated by article 81 of the Constitution.
} 
established by constitution that one of its attributes be exercised by an organ of the state, called The King ${ }^{27}$.

Thus, it was pointed out that executive power is not the property of the person who exercises it, a valid statement in our opinion, regardless of whether the executive is a monocratic one or a dualist one. The way executive power will be exercised is established by constitutional regulations.

The 1938 Constitution will maintain a monocratic executive, as the executive power was entrusted to the King, a unipersonal body, which, according to article 32, will exercise it by its own Government.

By the passing of constitutional law of September $1940^{28}$, the new regulations abolished the dictatorship of King Carol the Second, but this will not affect the structure of the Romanian executive, as it will still be a monocratic one regardless of whether it is the new king or the Field Marshall Ion Antonescu who will exercise executive power.

Thus, the prerogatives of the new King - Mihai the First, will be reduced until he will only hold honorary titles as: head of the armed forces, awarding decorations ${ }^{29}$, as all the other powers of the state were entrusted to the Minister's Council, which had "full powers to lead the State" 30 thus becoming the "pivot of the entire Romanian public life"

The time between 1944 and 1948 was marked by numerous social -political controversies and constitutional transformations. This will all put a serious mark on the executive's structure making it the more difficult to appreciate the monist or dualist character of the executive, even if by Decree no 1626 of August $31^{\text {st }}, 1944$, the provisions of the 1923 Constitution will be partly reinstated. Our point of view is based on the fact that although monarchy is maintained, the Minister's Council is transformed into "a supreme organ of the state, which had all state power, ${ }^{\text {, }}$. Subsequently, by Law no. 363 of December $30^{\text {th }}, 1947$ for the forming of the popular republic or Romania ${ }^{33}$, the task of exercising executive power will be granted to a collegial body - The Presidium of the People's Republic of Romania - which will have the Government as a subordinate. Thus, the executive can be qualified as being a monist one.

The following Romanian Constitutions, namely those of 1948 and 1952 establish a monist executive, represented by a collegial body, namely the Presidium of the National Legislative Assembly ${ }^{34}$, the Government or the Minister's Council, who only performed administrative duties.

\footnotetext{
${ }^{27}$ See P. Negulescu, Curs de drept constituţional român, published by Alex. Th. Doicescu, Bucharest, 1928, p. 415.

${ }^{28}$ Royal Decree no 3051 of September $5^{\text {th }}$, 1940 published in the Official Gazette of Romania, part I, no 205 of September $5^{\text {th }}$, 1940; Royal Decree no 3052 of September $5^{\text {th }}, 1940$ published in the Official Gazette of Romania, part I, no 205 of September $5^{\text {th }}$, 1940; Royal Decree no 3053 of September $5^{\text {th }}$, 1940 published in the Official Gazette of Romania, part I, no 205 of September $5^{\text {th }}, 1940$; Royal Decree no 3064 of September $6^{\text {th }}$, 1940 published in the Official Gazette of Romania, part I, no 206 bis of September 6 ${ }^{\text {th }}$, 1940; Royal Decree no 3067 of September $6^{\text {th }}, 1940$ published in the Official Gazette of Romania, part I, no 206 bis of September $6^{\text {th }}$, 1940; Royal Decree no 3072 of September $8^{\text {th }}, 1940$.

${ }^{29}$ P. Negulescu, G. Alexianu, Tratat de drept public, Tomul I, „Casa Şcoalelor” Publishing House, 1942, p. 232

${ }^{30}$ Ibidem.

${ }^{31}$ Ibidem. Current doctrine states the fact that in passing governing acts - law-decrees - the Field Marshall Ion Antonescu associated with King Mihai (See C. Ionescu, Tratat de drept constituţional contemporan, „All Beck” Publishing House, Bucharest, 2003, p. 518). However, the executive is dualist only in appearance as "the fundamental principle is that or leading, of an authoritarian leadership exercised by a single person - the Head of the State" (P. Negulescu, G. Alexianu, Tratat de drept public, Tomul I, “Casa Şcoalelor” Publishing House, 1942, p. 236).

${ }^{32}$ I. Muraru, Simina Elena Tănăsescu, Drept constituţional şi instituţii politice, "All Beck" Publishing House, Bucharest, 2001, p. 110.

${ }^{33}$ Published in the Official Gazette of Romania, part I, no. 300 bis of December $30^{\text {th }}, 1947$.

${ }^{34}$ Neither of these laws state, expresis verbis, those stated above, the only explanation refers to the abolition of the principle if separation of powers in state and the equilibrium of powers in state and the replacing of this principle with that of the confusion of powers. However, the logical and systematic interpretation of the constitutional
} 


\section{O. Şaramet}

The constitutional development of Romania after the events of 16-22 ${ }^{\text {nd }}$ December 1989 can be characterized by three stages: the stage of revolutionary power, the stage of revolutionary powers organized under from of the Legislative Assembly and the stage of legalizing the Revolution.

By the National Salvation's Front statement, published in the Romanian Official Gazette no 1 of December $22^{\text {nd }}, 1989$, the only central organs which were maintained were the ministries. By concentrating all legislative power in the hands of one collegial body that came from the Council of the National Salvation Front, the governing of the country was equivalent to "a factual governing performed by a group of people who undertook this responsibility all by themselves and acted according to the specific needs of those times" ${ }^{35}$. Because of this, it is nearly impossible to distinguish between organisms and state authorities in the sense of the separation of power theory, especially since the dualist of monist character of the executive can't be established.

Defined as a "revolutionary mini-constitution"36, the law-decree no. 2 of 1989 regarding the forming, organizing and functioning of the National Salvation Front and the territorial councils of the National Salvation Front formed a new body - the Council of the National Salvation Front, whose president had specific duties similar to those of a head of the state ${ }^{37}$. The same newly created Council will have as a duty, according to the provisions of article 2 alignment (1) letter $b$ ) the naming and revoking of the prime minister. By giving these duties to the Council of the National Salvation's Front, the new regime can be characterized as one "of assembly" in which "executive power comes from the legislative power who can revoke it at any time" ${ }^{38}$. As for the structure, the executive is a dualist one, represented by the President of the Republic and the Government ${ }^{39}$; however, placing the Government as a subordinate and granting the President the possibility to dissolve the legislative deprives the executive of the possibility to keep "its profile and the true power in state"

By the Law-Decree not 92/1990 for choosing the Parliament and the President of Romania a new political and judicial institution was created - the President of Romania, who exercised executive power along with the Government, headed by the prime-minister. Thus, the dualist structure of the executive was confirmed.

The dualist structure of the executive was maintained by the lawmaker of 1991, as well as following the 2003 revision of the Constitution, as a unipersonal body - head of the state and a collegial body - the Government. The Government will be supported in exercising its duties by the public administration which it will lead. This activity must not be understood in a restrictive way which would eventually translate by attributes of command and control as the relations between the Government and the pubic administration are those of subordination, collaboration

\footnotetext{
provisions, as well as appreciating the duties of this Presidium, stated by article 44 of the 1948 Constitution, article 37 of the 1952 Constitution will allow the support of this statement.

${ }^{35}$ T. Drăganu, Drept constituţional şi instituţii politice. Tratat elementar, vol. I, „Lumina Lex” Publishing House, Bucharest, 2000, p. 392.

${ }^{36}$ Ibidem. This Law-Decree was published in the Official Gazette of Romania no 4 of December $27^{\text {th }}, 1989$.

${ }^{37}$ According to article 5 of the Law-Decree, the President of the National Salvation Front's council had specific duties similar to those of a head of the state who exercises his function of representation: for example, representing the country in international relations, concluding international treaties, naming ambassadors. However, as doctrine pointed out, (See T. Drăganu, Drept constituţional şi instituţii politice. Tratat elementar, vol. I, "Lumina Lex" Publishing House, Bucharest, 2000, p 393) the duties are reduced as opposed to those of the president of a presidential republic, even a parliamentary one.

${ }^{38}$ T. Drăganu, Drept constituţional şi instituţii politice. Tratat elementar, vol. I, "Lumina Lex" Publishing House, Bucharest, 2000, pp. 274-276 and p. 393.

${ }^{39}$ By the Law-decree no 10 of 1989 regarding the forming, organizing and functioning of the Romanian Government, a supreme organ of state administration will be formed, namely the Romanian Government.

${ }^{40}$ T. Drăganu, Drept constituţional şi instituţii politice. Tratat elementar, vol. I, "Lumina Lex" Publishing House, Bucharest, 2000, p. 276.
} 
and administrative tutelage ${ }^{41}$; the nature of the relations between the Government and authorities and organs of the central public administration are identified by the fundamental law ${ }^{42}$.

\section{Conclusion}

Hence, at present times, identifying an executive as being monocratic, monist or dualist can be somewhat difficult, as there are constitutional systems in which it is difficult to appreciate an executive as having one form or another. The more or less formal prepotency of the head of state - monarch or president - in exercising executive power and its reports to the collegial body the other component of the executive, these all influence these identification.

On the other hand, to describe an executive as being monocratic does not mean that the body, the authority who exercises executive power is a unipersonal one; it can also be a collegial body. In regard to the number of members of the monist collegial executive, there are several forms $^{43}$ : duumvirate ${ }^{44}$ - the executive is formed of two equal members, triumvirate ${ }^{45}$ - the executive is formed of three people and the diarchy ${ }^{46}$ - the executive is formed from more than two members but it is no longer necessary for them to be on equal positions.

Within this dualist executive, the nature of the political regime established by the Constitution and which is influenced by the parliamentary one, the duties are split between a head of the state, represented by the President of the Republic, chose by universal and direct vote and a Government named by the President following the trust vote granted by the Parliament, to which it is accountable.

\footnotetext{
${ }^{41}$ See Dana Apostol Tofan, Drept administrativ, vol. I, “C.H. Beck” Publishing House, Bucharest, 2008, p. 150; A. Iorgovan, Tratat de drept administrativ, vol.I, “All Beck” Publishing House, Bucharest, 2005, p. 364

${ }^{42}$ Thus, for example, distinguishing between ministerial administration and extra ministerial one, article 116 of the republished Constitution, specifies the existence of subordination relations between the government and the ministries or other specialty bolides, as well as collaboration relations with autonomous administrative authorities. The same article mentions the existence of similar relations between the first ministries and specialty bodies which can be organized; alignments (1) and (2) of article 123 establishes other types of relations between the Government and the prefect, as well as the relations between the prefect and public services ad other organs of central public administration. However, article 123 alignment (4) will exclude any such relations between the prefect and authorities of the local public administration, as the mayor, local council, county council and the president of the county council. For the distinction between ministerial administration and extra ministerial administration, also see Dana Apostol Tofan, Drept administrativ, vol. I, “C.H. Beck” Publishing House, Bucharest, 2008, p. 150, or I. Vida, Puterea executivă şi administraţia publică, Regia Autonomă "Monitorul Oficial” Publishing House, Bucharest, 1994, pp. 127-128.

${ }^{43}$ D. C. Dănişor, Drept constituţional şi instituţii politice. Exerciţiul puterii în stat, vol.II, "Europa" Publishing House, Craiova, 1996, pp. 100-101.

${ }^{44}$ Such an example can be found in the time of the Roman Republic (509 BC. -27 BC.) when the King's role in leading the state was taken over by two consuls, whose duties will be limited throughout this regime by creating new magistracies. Their powers were limited because they were chosen for a year, subsequently becoming simple citizens who could be called in front of the people to answer for the acts passed while they were in function. See E. Molcuţ, D. Oancea, Drept roman, "Şansa" Publishing House and Univers Publishing House, 1993, p. 31.

${ }^{45}$ Such a form the monist collegial executive was regulated by the VIII ${ }^{\text {th }}$ year Constitution of France when, according to article 39, Bonaparte and Cambacérès were appointed consuls for a period of 5 years. Both of them, but especially Bonaparte had all the executive power. See M. Morabito, D. Bourmaud, Histoire constitutionnelle et politique de la France (1789-1958), „Montchrestien” Publishing House, Paris, 1996, pp. 133-134. A special form of the triumvirate can be seen is Bosnia-Herzegovina where, in an attempt to prevent interracial conflicts, article V stated that the presidency of this state must be formed of three members: a Croatian one and a Bosnian one, both chosen from the Federal territory and a Serbian one chosen from the territory of the Serbian Republic. This collegial body is close, in structure, to the Swiss one because, according to article V paragraph 2 letter b) of BosniaHerzegovina's constitution, the three members of the presidency will name one as the President. The one who received the largest number of votes was chosen for the first time; subsequently they all took turns or were chosen by the Parliamentary Assembly.

${ }^{46}$ The French constitution of year III (of August 22nd, 1795) entrusted executive power to a Directorate - a collegial body formed of 5 directors who were chosen by the legislative bodies. M. Morabito, D. Bourmaud, Histoire constitutionnelle et politique de la France (1789-1958), „Montchrestien” Publishing House, Paris, 1996, pp. 113 and following.
} 


\section{Bibliography}

- Dana Apostol Tofan, Drept administrativ, vol. I, "C.H. Beck" Publishing House, Bucharest, 2008;

- Iorgovan, Tratat de drept administrativ, vol.I, "All Beck" Publishing House, Bucharest, 2005;

- M. Constantinescu, A. Iorgovan, I. Muraru, Simina Elena Tănăsescu, Constituţia României revizuită - comentarii şi explicaţii, "All Beck" Publishing House, Bucharest, 2004;

- Ionescu, Tratat de drept constituţional contemporan, "All Beck" Publishing House, Bucharest, 2003;

- J. P. Jacqué, Droit constitutionnel et institutions politiques, "Dalloz" Publishing House, Paris, 2003;

- Elena Simina Tănăsescu, N. Pavel (coordinators), Actele constituţionale ale Regatului Unit al Marii Britanii şi Irlandei de Nord, All Beck Publishing House, Bucharest, 2003;

- I. Muraru, Simina Elena Tănăsescu, Drept constituţional şi instituţii politice, „All Beck” Publishing House, Bucharest, 2001;

- T. Drăganu, Drept constituţional şi instituţii politice. Tratat elementar, vol. I, "Lumina Lex" Publishing House, Bucharest, 2000;

- T. Drăganu, Drept constituţional şi instituţii politice. Tratat elementar, vol. II, "Lumina Lex” Publishing House, Bucharest, 2000;

- V. Duculescu, Constanţa Călinoiu, G. Duculescu, Constituţia României - comentată şi adnotată, "Lumina Lex" Publishing House, Bucharest, 1997;

- D.C. Dănişor, Drept constituţional şi instituţii politice. Exerciţiul puterii în stat, vol.II, "Europa" Publishing House, Craiova, 1996;

- M. Morabito, D. Bourmaud, Histoire constitutionnelle et politique de la France (17891958), "Montchrestien" Publishing House, Paris, 1996;

- I. Vida, Puterea executivă şi administraţia publică, Regia Autonomă "Monitorul Oficial" Publishing House, Bucharest, 1994;

- E. Molcuţ, D. Oancea, Drept roman, "Şansa" Publishing House and Univers Publishing House, 1993;

- M. Duverger, Les constitutions de la France, "P.U.F." Publishing House, Paris, 1987;

- J.Q. Wilson, American Government. Institutions and Policies, Harvard University and University of California, Los Angeles, 1986;

- A. Hauriou, Droit constitutionnel et institutions politiques, "Montchrestien" Publishing House, Paris, 1972;

- P. Negulescu, G. Alexianu, Tratat de drept public, Tomul I, "Casa Şcoalelor" Publishing House, 1942;

- P. Negulescu, Curs de drept constituţional român, published by Alex. Th. Doicescu, Bucharest, 1928. 